\title{
Changes in Activities of Several Enzymes for Carbohydrate Metabolism in the Rat Submaxillary Gland in Response to Experimental Diabetes and Insulin Treatment
}

\author{
by
}

Hajime MURAKAMI*

\section{Introduction}

It is well known that polydipsia related with hyperglycemia is commonly found under the diabetic condition. It may reasonably be assumed that such a situation has a marked influence on the function of the salivary gland, since fluid with the volume almost comparable to that of the urine is excreted from the salivary gland in the case of healthy human subjects. However, only a few studies have been made on the function of the salivary gland in relation with diabetes $[1,2,3]$.

In the present study, the author examined the activity of several enzymes for carbohydrate metabolism in the rat submaxillary gland under the experimental diabetic condition. In vitro study was also performed if insulin had a direct effect on the salivary gland.

\section{Materials and Methods}

Male rats of Donryu strain weighing about $150 \mathrm{~g}$ were used throughout. Experimental diabetes was induced in the rats by the intravenous injection of $40 \mathrm{mg} / \mathrm{kg}$ of streptozotocin (Upjohn International Inc.). On the 4th day, the rats were sacrificed by exsanguination from the carotid artery, and submaxillary glands were taken out. The glands were immediately homogenized in $0.1 \mathrm{M}$ Tris- $\mathrm{HCl}$ buffer $(\mathrm{pH} 7.4)$ with the use of Potter-Elvehjem glass homogenizer with ice chilling. The homogenate was centrifuged in an ultracentrifuge (Beckman-Spinco L3-40) at 105,000 $\times \mathrm{g}$ for $60 \mathrm{~min}$ and the resulting supernatant fraction was used for the enzyme assay.

Hexokinase activity was measured by the method of Walker [4], reading the increase in the absorption at $340 \mathrm{~nm}$ in the mixture of glucose, ATP, $\mathrm{Mg}^{++}$, glucose6-phosphate dehydrogenase, NADP and the supernatant fraction. Glucose-6-phosphate dehydrogenase activity was measured according to the method of Langdon [5] essentially in the same way as that for hexokinase activity with the exception that glucose-6-phosphate was added instead of glucose, ATP and glucose-6-phosphate dehydrogenase. Lactate dehydrogenase activity was measured also spectrophoto-

* 村上 元: Department of Physiology, Nihon University School of Dentistry, Matsudo, Matsudo, Chiba, Japan. 
metrically by reading the increase in the absorption at $340 \mathrm{~nm}$ in the mixture of lactate, NAD and the supernatant fraction by the procedure of Neilands [6]. Protein was determined by method of Lowry et al. [7] and blood glucose was determined by the procedure of Momose et al. [8]. In in vitro experiments, the submaxillary gland was minced and incubated at $37^{\circ} \mathrm{C}$ for $3 \mathrm{hrs}$. either in the presence or absence of 100 $\mathrm{mU} / \mathrm{ml}$ of insulin in Krebs saline serum substitute. After the incubation, the gland was homogenized and subjected to the same study for the enzyme activity as above.

\section{Results}

3.1 As shown in Table 1, the injection of streptozotocin caused a marked increase in the blood glucose level. Under such a diabetic condition, the weight of the submaxillary gland was significantly decreased. In accordance with those symptoms, the activities of hexokinase, glucose-6-phosphate dehydrogenase and lactate dehydrogenase were all decreased, the decrease being more marked in the former two.

Table 1. Changes of hexokinase activity, lactate dehydrogenase activity and glucose-6-phosphate dehydrogenase activity in the streptozotocin-induced diabetic rat submaxillary gland

\begin{tabular}{|c|c|c|c|c|c|c|}
\hline $\begin{array}{l}\text { (No. of } \\
\text { rats) }\end{array}$ & $\begin{array}{l}\text { Sub- } \\
\text { maxillary } \\
\text { gld. } \\
\text { Weight } \\
\text { (g) }\end{array}$ & $\begin{array}{l}\text { Blood } \\
\text { glucose }\end{array}$ & $\begin{array}{c}\text { Protein } \\
\text { in the } \\
\text { supernatant } \\
\text { fraction } \\
\mathrm{mg} / \mathrm{g} \\
\text { wet tissue }\end{array}$ & $\begin{array}{c}\text { Hexokinase } \\
\text { activity }\end{array}$ & $\begin{array}{l}\text { Lactate } \\
\text { Dehydro- } \\
\text { genase } \\
\text { activity } \\
\text { m units/mg } \\
\text { protein }\end{array}$ & $\begin{array}{c}\text { Glucose-6- } \\
\text { phosphate } \\
\text { Dehydrogenase } \\
\text { activity } \\
\text { m units/mg } \\
\text { protein }\end{array}$ \\
\hline $\begin{array}{c}\text { Control } \\
\text { (4) }\end{array}$ & $0.60 \pm 0.06$ & $106.3 \pm 5.21$ & $74.4 \pm 7.29$ & $\begin{array}{l}58.1 \pm 1.48 \\
(100)\end{array}$ & $\begin{array}{c}8.58 \pm 0.38 \times 10^{2} \\
(100)\end{array}$ & $\begin{array}{l}56.7 \pm 11.6 \\
(100)\end{array}$ \\
\hline $\begin{array}{l}\text { Treatment } \\
\text { (4) }\end{array}$ & $0.46 \pm 0.05$ & $483.3 \pm 3.03$ & $77.1 \pm 6.63$ & $\begin{array}{c}37.6 \pm 1.08 \\
(64.7)\end{array}$ & $\begin{array}{c}6.08 \pm 0.79 \times 10^{2} \\
(70.5)\end{array}$ & $\begin{array}{c}21.7 \pm 3.6 \\
(62.0)\end{array}$ \\
\hline
\end{tabular}

Values are given as means JI standard error of the means. ( ): $\%$ of control

Treatment: Streptozotocin $(40 \mathrm{mg} / \mathrm{kg})$ was intravenously injected into the rat.

The submaxillary glands were removed from animals 4 th day after the injection of streptozotocin.

Table 2. Changes of hexokinase activity and glucose-6-phosphate dehydrogenase activity in insulin treatment-rat submaxillary gland

\begin{tabular}{lccc}
\hline Group & $\begin{array}{c}\text { Protein in the } \\
\text { supernatant fraction } \\
\mathrm{mg} / \mathrm{g} \text { wet tissue }\end{array}$ & $\begin{array}{c}\text { Hexokinase } \\
\text { m units/mg } \\
\text { protein }\end{array}$ & $\begin{array}{c}\text { Glucose-6-phosphate } \\
\text { activity } \\
\text { m unit/mg protein }\end{array}$ \\
\hline Control & $72.3 \pm 10.25$ & $32.3 \pm 4.40$ & $7.7 \pm 2.40$ \\
Treatment & $60.3 \pm 1.25$ & $39.8 \pm 0.00$ & $18.3 \pm 1.95$ \\
\hline
\end{tabular}

Treatment: The minced submaxillary gland was incubated in $\mathrm{KSSS}$ medium at $37^{\circ} \mathrm{C}$ for 3 hrs with $100 \mathrm{mU} / \mathrm{ml}$ insulin. 
3.2 On the other hand, in vitro experiment was undertaken to clarify if such a change in the enzyme activity in the submaxillary gland was due to the direct effect of the insulin deficiency or secondary one following the metabolic disturbance under the diabetic condition. As shown in Table 2, the activity of hexokinase as well as that of glucose-6-phosphate dehydrogenase was increased by the addition of insulin to the incubation medium, the increase being marked in the latter case.

\section{Discussion}

The amount of salivary flow is a sensitive index of the state of hydration of the living body. Dehydration and decreased salivary secretion may result from decreased fluid intake or excessive loss of fluid. The reduced salivary secretion may also result from various factors affecting the secretory process, including atrophy of the salivary gland tissue [9]. It has been known that balance of hydration and dehydration is disturbed in diabetes mellitus. However, few study have been performed so far on the changes in the salivary gland under the diabetic condition, though numerous studies have been carried out morphologically and biochemically on the changes in various tissues. Shafer et al. [10] described that the xerostomia in diabetic patients was caused by systemic dehydration as a result of hyperglycemia-induced diuresis. Xerostomia, reduced salivary flow causes symptoms in oral cavity (e.g. increased caries, periodontal disease) and difficulties in physiological function (e.g. difficulty in chewing and swallowing). TAKAOKA et al. [2] reported on the hypertrophy of the parotid gland in patients with diabetes mellitus. FREUDENBERG [1] also observed the enlargement of the parotid gland associated with diabetes mellitus in the clinical observation. On the other hand, LIU and LIN [3] observed atrophy of the submandibular and parotid glands in the alloxan-induced diabetic rat.

The present study indicated that the submaxillary gland of the rat was atrophied by the induction of experimental diabetes by streptozotocin. In addition, the activities of enzymes for carbohydrate metabolism were significantly decreased by diabetes.

These findings indicate that the submaxillary gland may be sensitive either to insulin deficiency or to hyperglycemia. Since the enzyme activity was expressed as the specific activity (activity per protein in the supernatant fraction) and the amount of the protein per tissue was almost unchanged, the total activity of three enzymes in the gland of the diabetic rat was about a half of or less than that of the control for all the three enzymes. Such a decrease in the enzyme activity may result in the hypofunction of the salivary gland, which in its turn, may lead to the aggravation of the systemic symptoms. The results of the in vitro experiment revealed that such a change in the submaxillary gland brought about by diabetes might be due to the insulin deficiency, since the activity of both hexokinase and glucose-6-phosphate dehydrogenase was increased by the addition of insulin to the incubation medium. To the author's knowledge this is the first report showing the direct effect of insulin on the salivary gland. It seems to be of interest whether such a change in the enzyme activity is simply a pathological feature of diabetes or some kind of the adaptation of the body related to polydipsia or xerostomia.

More detailed systematic investigations to examine the changes of these enzymes of the gland in diabetic condition or in insulin treatment are now in progress. 


\section{Summary}

The changes of activities of hexokinase, lactate dehydrogenase and glucose-6dehydrogenase were examined in the submaxillary gland of streptozotocin-induced diabetic rats and in that treated with insulin in vitro. Atrophy of the submaxillary gland and the decreases in activities of those enzymes were observed in the diabetic rats. On the other hand, activities of those enzymes were increased by insulin. It was discussed that findings may be related to the oral physiological dysfunction and several symptoms caused in the oral cavity in patients with diabetes mellitus.

\section{Acknowledgement}

The study was supported in part by Nihon University Grant. The author is grateful to Drs. S. Ishibashi and K. Murakami for their helpful discussion and advice.

\section{References}

[1] Freudenberg, E.: Special form of diabetes associated with recurrent swelling of salivary gland, Ann. Paediat.; 164, 53-58, (1945).

[2] Takaoka, Y., Ozaka, K. and Yakawa, S.: Hypertrophy of parotid gland in diabetes mellitus and internal secretion salivary glands; Jap. Med. J., 3, 199-207, (1950).

[3] LiU, F. T. Y. and LiN, H. S.: Role of insulin in body growth of salivary and endocrine gland in rats; J. Dent. Res. 48, 559-567, (1969).

[4] Walker, D. G.: On the presence of two soluble glucose-phosphorylating enzymes in adult liver and the development of one of those after birth; Biochim. Biophys. Acta, 77, 209-226, (1963).

[5] Langdon, R. G.: Glucose-6-phosphate dehydrogenase from erythrocytes, in Method in Enzymology; 9, 126-131, (1966). Academic Press, London \& New York.

[6] Neilands, J. B.: Lactate dehydrogenase of heart muscle, in Methods in Enzymology; 1, 449454, (1955). Academic Press, London \& New York.

[7] Lowry, O. H., Rosenbrough, N. J., Farr, A. L. and Randall, R. J.: Protein measurement with the Folin phenol reagent; J. Biol. Chem., 193, 265-275, (1951).

[8] Momose, T., Inada, A., Mukai, Y. and Watanabe, M.: Organic analysis, XXIII, Determination of blood sugar and urine sugar with 3,6-dinitrophthalic acid; Talanta 4, 33-37, (1960).

[9] Spouge, J. D.: Oral Pathology; C. V. Mosby Co., Saint Louis, p. 425, (1973).

[10] Shafer, W. G., Hine, M. K. and Levy, B. M.: Developmental disturbances of oral and paraoral structure, in A Text book of Oral Pathology (2nd ed.); Philadelphia and London: W. B. Saunders Co., p. 32, (1963). 